\title{
Tourist Satisfaction Towards Arabica Coffee at Catur Village Kintamani Bangli - Bali
}

\author{
Ni Luh Suastuti \\ Food and Beverage Management Program \\ Sekolah Tinggi Pariwisata Nusa Dua Bali \\ Badung, Bali \\ suastuti@gmail.com
}

\section{ABSTRACT}

Coffee lovers around the world is growth very fast recently. These phenomena can be seen from the development of various coffee franchise companies and number of coffee shop is also growth in all over the world. The increasing of this trends of coffee also has a positive impact on local Balinese coffee. The developing of tourism in Bali can give the opportunity to Bali coffee Kintamani to be developed. Catur village is a center of Kintamani's arabica coffee producer. As a prominent agropolitan farming area, the arabica coffee plantation plant reaches an area of 470 hectares. Arabica coffee is cultivated among citrus plants (Citrus grandis,) so that the coffee produced is very typical, an orange flavored Arabica coffee (Citrus grandis), this is strongly influenced by local natural conditions, because Catur Village is not only known as a center of arabica coffee production, it is also known. as a center of red orange (Citrus grandis). Coffee is traditionally cultivated, using only organic or non-chemical fertilizers, without using chemical or inorganic fertilizers, as well as eradicating plant pests and diseases without using chemical pesticides. Arabica coffee plantations among citrus plants potentially be developed as agro tourism. The objective of this research was to determine the level of tourist satisfaction with Bali coffee in Catur Kintamani Bangli Village, Bali. The research question is what is the level of tourist satisfaction with Arabica Coffee at Catur Kintamani Bangli - Bali. This study uses 93 respondents' of foreign tourists who have tried coffee arabica from Catur Village Kintamani Bangli Bali. This study uses 11 coffee indicators (aroma, acidity, flavor, body of coffee, sweetness, coffee variation, portion size, presentation of coffee, cleanliness of coffee equipment, price of coffee, and serving of coffee). The analysis used in this study is Important Performance Analysis and Customer Satisfaction Index. The finding of this research are The results of the Importance Performance Analysis (IPA) shows that the coffee indicators need to be improved are acidity, cleanliness of coffee equipment, body of coffee, sweetness of coffee, and portion size of Bali Kintamani arabica coffee. Based on the results of the Customer Satisfaction Index (CSI) analysis, it was found that the level of tourist satisfaction with Bali Kintamani coffee was $93.2 \%$. there are very satisfied criteria.

Keywords - rabica Coffee Kintamani, Tourist Satisfaction, Customer Satisfaction

\section{INTRODUCTION}

Indonesia as an agricultural country produces a lot of coffee with various varieties. Indonesian coffee is widely sold in Western countries such as America. Even Sumatran luwak coffee is the most expensive coffee in the world. Sumatra coffee has long been one of the best-selling commodities in America known as a country with the largest level of coffee consumption. Because coffee can only grow from countries located around the equator, then almost every year, US employers import coffee from several countries located around the equator. This shows that there are high opportunities, especially for the tourism sector to be able to sell local coffee products to foreign tourists. The high price of Indonesian coffee abroad can be used as an indication that the quality of Indonesian coffee is quite recognized. To be able to increase local coffee sales, it is important to know how foreign tourists view local coffee itself in terms of price, product quality, and coffee flavor.

Kintamani is one of the tourist destinations in Bangli Regency, Bali, Indonesia. This area is known for its Mount and Lake Batur attractions and Kintamani Oranges fruit. Not many people know that Kintamani coffee is one of the best origin coffee in Indonesia and has been exported to America since 1825. Kintamani coffee has high coffee and high reputation because it is planted by the people who have care about quality of the coffee. Kintamani Bali Coffee has a long history and because of its local cultural traditions and high quality. The taste profile of Kintamani Bali coffee is: 1). Free from major taste defects, 2). Clean acidity taste from moderate to high levels, 3). Bitter taste that is lacking or completely undetectable, 4). Strong quality and intensity of aroma, sometimes with fruit flavor (especially orange juice). This profile is similar to Javanese coffee, while the difference is that in Bali Kintamani Coffee is often more prominent in fruit (orange) aroma while in Java coffee the aroma of the spices is more prominent. Coffee Kintamani will certainly be able to boost Kintamani as a tourism destination. Ttourists will visiting Kintamani not only for beautiful scenery and cool air, but also can enjoy coffee both as a product and as an agrotourism. Kintamani coffee can be a new icon for tourism in Kintamani. The high potential of Kintamani Coffee needs to be maximized by well organized and managed. Understanding of tourist satisfaction towards Bali Kintamani Coffee becoming very importance because by fulfilling customer satisfaction, it can create customer loyalty. If the 
customer is loyal then they tend to continue to use the product and can recommend the product to others, thus sales will be able to increase significantly. Satisfaction is the customer's response to the fulfillment of needs. Satisfaction is a function of perception or impression of performance and expectations. If the performance is below expectations, then the customer becomes dissatisfied and if the performance exceeds expectations, the customer will feel satisfied. By knowing the level of customer satisfaction, a business can determine the right marketing strategy to survive in competition.. Thus, it is necessary to conduct research on the Tourist satisfaction towards Arabica Coffee at Catur Village Kintamani.

The objective of this research was to determine the level of tourist satisfaction with Bali coffee in Catur Kintamani Bangli Village, Bali. The research question is what is the level of tourist satisfaction with Arabica Coffee at Catur Kintamani Bangli - Bali.

This study uses 93 respondents' of foreign tourists who have tried coffee Arabica from Catur Village Kintamani Bangli Bali. This study uses 11 coffee indicators (aroma, acidity, flavor, body of coffee, sweetness, coffee variation, portion size, presentation of coffee, cleanliness of coffee equipment, price of coffee, and serving of coffee). The analysis used in this study is Important Performance Analysis and Customer Satisfaction Index.

\section{THE MAIN CONTENT}

In terms of demographics, respondents of this study is analyzed from several aspects, including Country of origin, age, gender, marital status, number of visits, and purpose of visiting. Data on respondents' demographics can be seen from Table 1:

\begin{tabular}{|c|c|c|c|}
\hline Demography & Description & & $\begin{array}{l}\text { Number } \\
\text { respondents }(\%)\end{array}$ \\
\hline \multirow[t]{4}{*}{ Country of origin } & Australis & New & $21(22,58 \%)$ \\
\hline & Zealand & & \\
\hline & Europe & & $(68,82 \%)$ \\
\hline & Asia & & $8(8,60 \%)$ \\
\hline \multirow[t]{2}{*}{ Gender } & Female & & $49(52,69 \%)$ \\
\hline & Male & & $44(47,31 \%)$ \\
\hline \multirow[t]{2}{*}{ Marital status } & Single & & $64(68,82 \%)$ \\
\hline & Married & & $29(31,18 \%)$ \\
\hline \multirow[t]{3}{*}{ Occupation } & Professionals & & $86(92,47 \%)$ \\
\hline & Business & & $7(7,53 \%)$ \\
\hline & Retirement & & $0(0 \%)$ \\
\hline \multirow[t]{3}{*}{ Number of visit } & Once & & $21(22,58 \%)$ \\
\hline & Twice & & $35(37,63 \%)$ \\
\hline & Three & or & $37(39,78 \%)$ \\
\hline \multirow[t]{3}{*}{ Purpose of visit } & more & & $14(15,05 \%)$ \\
\hline & Vacation & & $79(84,95 \%)$ \\
\hline & Business & & $0(0 \%)$ \\
\hline \multirow[t]{5}{*}{ Age } & Self-development & & $78(83,87 \%)$ \\
\hline & 21-35 years & & $15(16,13 \%)$ \\
\hline & $36-50$ years & & $0(0 \%)$ \\
\hline & $51-65$ years & & $0(0 \%)$ \\
\hline & 65 years + & & \\
\hline
\end{tabular}

Based on the data in Table 1 above it can be seen that viewed from the country of origin, the most respondents come from Europe, followed by respondent from Australia and New Zealand and Asia. From gender, most of the respondents were female. Most of the respondents were single / unmarried. From the age group dominated by respondents from the young age group that is in the age range of 21-35 years and followed by the age $36-50$ years old. Whereas when viewed from the occupation, most of the respondents are professionals. From the number of visits, most of the respondents have been to Bali before (repeated guest).

\section{A. Tourist Satisfaction Performance on Arabica Bali Kintamani coffee}

The results of the average level of tourist satisfaction on Arabica Bali Kintamani coffee can be seen in Table 2 below:

Table 2. Tourist Satisfaction Performance on Arabica Bali Kintamani coffee

\begin{tabular}{lcc} 
Coffee Aroma & 4,85 & Very Good \\
Acidity of coffee & 4,45 & Very Good \\
Flavor of coffee & 4,76 & Very Good \\
Body of coffee & 4,39 & Very Good \\
Sweetness & 4,61 & Very Good \\
Coffee variation & 4,69 & Very Good \\
Portion size & 4,54 & Very Good \\
Presentation & 4,85 & Very Good \\
Cleanliness of & 4,60 & Very Good \\
coffee equipment & & \\
Price & 4,70 & Very Good \\
Serving of coffee & 4,77 & Very Good \\
\multicolumn{1}{c}{ Average : } & $\mathbf{4 , 6 6}$ & Very Good \\
& &
\end{tabular}

From 11 indicators of coffee, all indicators are rated very well by respondents. The aroma of coffee and coffee presentation was rated best with a score of 4.85. this shows that tourists love the aroma of Bali Kintamani coffee and presentation from Arabica coffee Kintamani. This is indeed very suitable considering that Kintamani coffee has a very distinctive citrus / orange aroma. While the coffee attribute that gets the lowest value is the body of coffee. Kintamani coffee is considered to have a light character in the mouth (light body) by respondent. This is very much in line with the theory that Bali Kintamani coffee has a light body character. Overall consumer ratings of Bali kintamani coffee are very good with a value of 4.66 .

\section{B. Importance Performance Analysis/IPA}

The level of conformity is a comparison between the performance score and the degree of Importance score which will determine the priority sequence of the performance improvement of each attribute in the tourist satisfaction variable in one quadrant. The higher the percentage level of conformity, the higher the satisfaction of tourists towards the coffee attributes. According to Sukardi and Cholidis, if the value of the suitability level approaches $100 \%$ and is above the average then it can be said that the level of conformity is good. Calculation of conformity level can be seen in the following Table 3: 
Table 3 Level of Conformity between satisfaction performance level and level of importance

\begin{tabular}{lccc}
\hline Attributes & $\begin{array}{c}\text { Performance } \\
\text { Score } \\
(\mathrm{Xi})\end{array}$ & $\begin{array}{c}\text { Importance } \\
\text { Score (Yi) }\end{array}$ & $\begin{array}{c}\text { Level of } \\
\text { Conformity } \\
(\%)\end{array}$ \\
\hline Coffee Aroma & 451 & 401 & 112,47 \\
Acidity of coffee & 414 & 435 & 95,17 \\
Flavor of coffee & 443 & 444 & 99,77 \\
Body of coffee & 408 & 400 & 102,00 \\
Sweetness & 429 & 430 & 99,77 \\
Coffee variation & 436 & 428 & 101,81 \\
Portion size & 422 & 430 & 98,14 \\
Presentation & 451 & 443 & 101,81 \\
Cleanliness of & 428 & 443 & 96,61 \\
coffee equipment & & & \\
Price & 437 & 437 & 100 \\
Serving of coffee & 444 & 465 & 95,48
\end{tabular}

Based on Table 3 above it can be seen that of the 11 attributes about tourist satisfaction with Arabica Bali Kintamani coffee, there are six attributes / variables whose suitability level is below $100 \%$. Improved performance on variables that have a level of suitability below $100 \%$ is necessary to improve tourist satisfaction with Bali Kintamani coffee, such as the cleanliness of the tools used in making and serving coffee needs to be considered, how to serve coffee, and portion sizes need to be considered more .

Analysis using Cartesian diagram in determining the position in the quadrant where an attribute is located can be done by calculating first the average level of performance attributes and level of importance of attributes. The next calculation is to calculate the average of the level of performance / satisfaction and the level of importance of tourists which can be seen in Table 4 below:

Table 4. Level Degree of Importance and Performance of Arabica Bali Kintamani coffee

\begin{tabular}{lll}
\hline \multicolumn{1}{c}{ Atribute } & $\begin{array}{l}\text { Average } \\
\text { Performance }\end{array}$ & $\begin{array}{c}\text { Averages } \\
\text { Degree of } \\
\text { importance }\end{array}$ \\
\hline Coffee Aroma & 4,85 & 4,31 \\
Acidity of coffee & 4,45 & 4,68 \\
Flavor of coffee & 4,76 & 4,77 \\
Body of coffee & 4,39 & 4,30 \\
Sweetness & 4,61 & 4,62 \\
Coffee variation & 4,69 & 4,60 \\
Portion size & 4,54 & 4,62 \\
Presentation & 4,85 & 4,76 \\
Cleanliness of & 4,60 & 4,76 \\
coffee equipment & & \\
Price & 4,70 & 4,70 \\
Serving of coffee & 4,77 & 5,00 \\
Average : & $\mathbf{4 , 6 6}$ & $\mathbf{4 , 6 5}$
\end{tabular}

Looking at the data in the table above it can be seen that the rating of tourists on the satisfaction performance of tourists gets an average value of 4.66 with the lowest value of 4.39 for the attributes of the body of coffee and the highest value of 4.85 for the aroma of coffee and the presentation of coffee . The average rating of tourists on Bali Kintamani coffee is 4.65 , with the lowest rating range of 4.30 for the body of coffee attribute and the highest range of 5.00 for the serving of coffee attribute.

Describing the distribution of attributes in the Cartesian Diagram is used to determine the position of each of the attributes of tourist satisfaction towards arabica Bali Kintamani coffee, whether it is located in a position that must be repaired or lies in a position that must be maintained (Supranto, 2006). The Cartesian Diagram is divided into four regions which are limited by the average value of the level of tourist satisfaction performance of Bali Kintamani coffee. all attributes of 4.66 on the $\mathrm{X}$ axis and the average rating of the tourist importance level on Bali Kintamani coffee all attributes of 4.65. On the $\mathrm{Y}$ axis, the location of each attribute in each quadrant is shown in Figure 1 below:

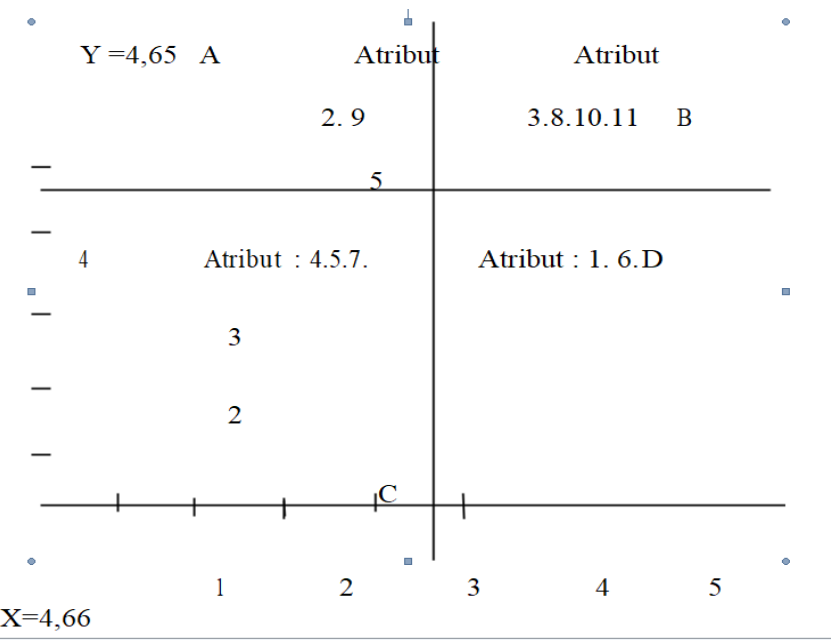

Figure 1 : Cartesians Diagram

Quantity A is a quadrant that shows that the attribute / variable of Bali Kintamani coffee in Kintamani District Bali is an important variable for tourists, but Kintamani coffee apparently has not been able to reach the expectations of tourists. Variables in quadrant A are a priority for tourists and need more attention for Bali Kintamani coffee sellers. Variables included in quadrant A include Acidity variable or coffee acidity level and cleanliness of coffee equipment variable. Acidity of coffee is a very important element and must be present in coffee drinks. This happens because the coffee brewing technique is less precise, such as the size of the coffee powder that is used inappropriately, grind size or degree of refinement of coffee powder or it could be the roasting profile is not right. Since 2003 Bali Kintamani coffee has been sampled and researched. In the degree of medium roast, the results are obtained if Balinese Kintamani coffee has a sweet aroma and there is a slight taste of spices. The results of the sensorial analysis show that the taste of 
Bali Kintamani coffee has a regular level of acidity that meets the strong quality and intensity of the aroma. This is what makes tourists already have high expectations for the acidity of Kintamani Bali Coffee.For the cleanliness of the tools used in making Bali Kintamani coffee, it needs to be further enhanced by Bali Kinatamani coffee sellers so that tourists are more satisfied with the quality of Bali Kintamani coffee. As we know the cleanliness factor in the presentation of products, especially food and beverage products for tourists needs to get serious attention. Cleanliness is indeed a high priority for tourists today.

Important for tourists and the performance of this variable has also been very satisfying for tourists to Bali Kintamani coffee. This is certainly very good and needs to be maintained by the Kintamani coffee sellers. There were four variables included in the Quadrant B: flavor of Bali Kintamani coffee, presentation of Bali Kintamani coffee, variable price of Bali Kintamani coffee, and variable way of serving coffee in its entirety. Seeing the four variables that enter quadrant $\mathrm{B}$ are indeed very suitable with the conditions in the field. Bali Kintamani coffee is known as coffee which has good flavor, namely citrus / orange and a little spice. This is because the farmers in Kintamani are well aware of the importance of the production process starting from harvesting and drying process, which can ultimately create a very distinctive aroma of coffee. Kintamani Coffee also has quite affordable prices and the presentation is also various - as presented as art, manual brew, etc.

Quadrant C is the quadrant that contains the variables of Bali Kintamani coffee that are considered less important by tourists and in fact the performance of this variable is also not good. variables included in this quadrant include: variable body of coffee, sweetness / sweet aroma of coffee, and coffee portion size. Bali Kintamani Coffee does have a unique taste Bali Kintamani coffee has fresh and sour fruit flavors due to the planting of Kintamani coffee along with vegetable plants and fruits and vegetables with a tumpang sari system. The taste of Kintamani coffee is also soft and not heavy or medium body. Body of coffe means the weight of the coffee, the weight is not in the sense of quantity, but in the sense of whether the coffee feels full / heavy in our mouth when coffee is smoked. When we drink coffee and feel heavy in the mouth it is called full body and if coffee is drunk, coffee feels light, it's called a light body. Kopi Bali Kintamani has a medium body so it's true that the coffee tends not to be too heavy and the tourists don't mind. But in the future coffee sellers must be able to brew Kintamani coffee properly so that the coffee body can come out optimally and the sweetness is also felt. The portion size of coffee also needs to be increased in the future.

Quadrant D shows the variable tourist satisfaction towards Bali Kintamani coffee which is not important for tourists and is considered too excessive. Kintamani Coffee sellers prioritize this variable so that tourists are very satisfied with this variable. Included in this quadrant is the variable Aroma Coffee and variations in coffee. The aroma of Balinese Kintamani coffee has also been famous for its strong aroma and varied presentation such as espresso, cappuccino, coffee latte, etc.
Looking at the results of the Cartesians diagram analysis above it can be said that quadrant $\mathrm{A}$ is a top priority to be improved because it is very important for tourists. The cleanliness of coffee equipment needs to be improved and the level of acidity of coffee also needs to be considered because these two variables are very important for tourists, so that tourism satisfaction with Bali Kintamani coffee can be increased.

\section{Customer Satisfaction Index (CSI)}

Calculation of the Customer Satisfaction Index (CSI) of Bali Kintamani coffee can be seen in Table 5 below:

Table 5. Customer Satisfaction Index (CSI) of Bali Coffee Kintamani

\begin{tabular}{lccc}
\hline \multicolumn{1}{c}{ Atribute } & $\begin{array}{c}\text { Averages } \\
\text { Importance } \\
\text { Performance } \\
\text { score }\end{array}$ & Weight Factor & $\begin{array}{c}\text { Average } \\
\text { Satisfaction } \\
\text { Score }\end{array}$ \\
\hline Coffee Aroma & 4,31 & 0,0843 & 4,85 \\
Acidity of coffee & 4,68 & 0,0915 & 4,45 \\
Flavor of coffee & 4,77 & 0,0933 & 4,76 \\
Body of coffee & 4,30 & 0,0841 & 4,39 \\
Sweetness & 4,62 & 0,0904 & 4,61 \\
Coffee variation & 4,60 & 0,0900 & 4,69 \\
Portion size & 4,62 & 0,0904 & 4,54 \\
Presentation & 4,76 & 0,0931 & 4,85 \\
Cleanliness of & 4,76 & 0,0931 & 4,60 \\
coffee equipment & & & 4,70 \\
Price & 4,70 & 0,0919 & 4,77 \\
Serving of coffee & 5,00 & 0,0978 & \\
Average : & $\mathbf{4 , 6 5}$ & $\mathbf{1 . 0 0 0 0}$ & \\
Weighted Total & & & \\
(WT) & & & \\
CSI = (4,66:5)X & & & \\
$\mathbf{1 0 0 \%}=\mathbf{9 3 . 2 \%}$ & & & \\
& & &
\end{tabular}

Customer Satisfaction Index (CSI) is a measure used to measure the percentage of satisfaction of tourists or consumers. CSI value is obtained by dividing the Total Weight with a maximum scale of five and multiplying the result by $100 \%$. From Table 5 above it can be seen that the value of tourist satisfaction index on Balinese coffee is at a value of 0.932 with a percentage of tourist satisfaction of $93.2 \%$. If seen in Table 5 below about the range of Performance of Consumer Satisfaction, it can be said that the level of tourist satisfaction with Bali Kintamani coffee is very satisfied.

Table 6. Range of Consumer Satisfaction Performance

\begin{tabular}{cc}
\hline CSI Value & CSI criteria \\
\hline $0,81-1,0081 \%-100 \%)$ & Very satisfied \\
$0,66-0,80(66 \%-80 \%)$ & Satisfied \\
$0,51-0,65(51 \%-65 \%)$ & Enough \\
$0,35-0,50(35 \%-50 \%)$ & Less Satisfied \\
$0,00-0,34(0 \%-34 \%)$ & Not Satisfied
\end{tabular}


With the high CSI value of $93.2 \%$ (very satisfied) it should not make Bali Kintamani coffee sellers satisfied because there are still $6.8 \%$ of tourists who are not so satisfied with the quality of Bali Kintamani coffee. Important attributes need serious attention for the Bali Kintamani coffee sellers.

\section{CONCLUSION}

The results of the Importance performance analysis (IPA) analysis show that the variables that are the top priority for performance improvement are variables in quadrant $\mathrm{A}$, namely the Acidity variable or the level of acidity and cleanliness of coffee equipment (coffee equipment). Other attributes that need to be improved are those in quadrant $\mathrm{C}$, namely the variable body of coffee, sweetness od coffee, and size portion of Bali Kintamani coffee drinks. This is caused by improper brewing methods such as coffee powder / dose which is used incorrectly, roasting profile or the level of maturity of roasting coffee beans is also less precise, and the size or smoothness in grinding coffee beans is less precise so the coffee character Kintamani doesn't come out maximally.

Based on the results of the Customer Satisfaction Index (CSI) analysis, it was found that the level of tourist satisfaction with Bali Kintamani coffee was $93.2 \%$. This value is located in the range of $0.81-1.00(81 \%-100 \%)$ which indicates that the tourist satisfaction index of Bali Kintamani coffee is very satisfied.

Based on the results of this study there are some suggestions that can be suggested:

1. Coffee brewing needs to be improved so that the character of Kintamani coffee can come out optimally and tourists are more satisfied with Bali Kintamani coffee. The Baristas need to be trained to do the right brewing especially for manual brewing and espresso methods.

2. Roasting Bali Kintamani coffee (roasting profile) should be at medium roast level so that the character of Bali Kintamani coffee can come out maximally like orange aroma, sweetness of Kintamani coffee is also quite smelled after brewing, the coffee tastes savory with little sensation of acidity left behind in the mouth with after taste sweet ones like caramel.

\section{REFERENCES}

[1] Asfirmanto,WA.,dkk. 2013. Pengaruh Kondisi Fisik dan Budidaya terhadap Kualitas Kopi di Kintamani dan Gayo. Fakultas MIPA Universitas Indonesia.

[2] Damanik,P.A,dkk, Analisis Kepuasan Konsumen terhadap Kualitas Kopi dengan metode Importance Performance Analisis (IPA) dan Customer Satisfaction Index (CSI) di coffee Story Malang.

[3] Dewi, D.2012. Sehat dengan secangkir Kopi. Surabaya : Penerbit Plus

[4] Freeman, James, dkk. 2012.The Blue Bottle Craft of Coffee. Berkeley: Ten Speed Press.

[5] Kotler, P 2003. Marketing Management. Prentige Hall, New Jersey.Soelasih, Y. 2004.Analisis Kepuasan Pelanggan terhadap kualitas Pelayanan di Hotel X di Jakarta. Jurnal Bisnis, Vol 4 No.2 Tahun 2003.

[6] Mahadewi, B.2009. 40 Resep Kopi Paling favorit. Jakarta : Araska

[7] Moldvaer,Anette.2014. Coffee Obsession . London : Dorling Kindersley Limited

[8] http://www.kedaimerahputih.com/2013/05/kopi-sumaterakopi-termahal-di-amerika.html, diunduh tanggal 24 Pebruari 2014

[9] https://www.kopikopen.com/blog/kopi-bali-kintamani/ (2015), diunduh tanggal 18 Mei 2017

[10] https://id.wikipedia.org/wiki/Kopi, diunduh tanggal 21 Juni 2017.

[11] https://kumparan.com/pinus-coffee/4-jenis-kopi, diunduh tanggal 21 Juni 2017.G. Eason, B. Noble, and I. N. Sneddon, "On certain integrals of Lipschitz-Hankel type involving products of Bessel functions," Phil. Trans. Roy. Soc. London, vol. A247, pp. 529-551, April 1955. (references)

[12] Sukardi dan Chodilis Chandrawatisma, 2006. Analisis Tingkat Kepuasan Pelanggan terhadap Produk Cornet Produksi PT CIP, Denpasar, Bali. Jurnal Teknologi Industri Pertanian. Vol.18 (2). Hal 106-117.

[13] Supranto, J.2006. Pengukuran Tingkat Kepuasan pelanggan Untuk Menaikkan Pangsa Pasar. Reika Cipta. Jakarta.

[14] Wadi. Hanzan dan Rahanatha. Bayu. Hubungan Variabel Demografi dengan Respon Konsumen terhadap Iklan Produk Kopi Merek Top Coffee di Kota Denpasar. 